\title{
Military Budget and Economic Growth : Case of Middle East, North Africa and South Asia Countries
}

\author{
Ratni Heliati \\ ratniheliati@yahoo.com \\ Intan Putri Wandiva \\ Faculty of Economic and Business, Universitas Padjadjaran
}

\begin{abstract}
Conflict became one of the biggest problems in the Middle East region. This situation will deteriorated the country and will impact on economic perfomance, so defense budget is important to resolve these problems. This study aims to determine the effect of military budget on economic perfomance in 22 countries of the Middle East, North Africa and South Asia 2000-2014 period. This study uses 5 variables namely GDP per capita, military budget, gross capital formation, human capital and final consumption expenditure. This study uses panel data analysis with fixed effect model. The results of model estimation suggest that military budget has a significant negative effect on economic perfomance, while gross capital formation, final consumption expenditure have significant positive effect on economic perfomance. Meanwhile, human capital does not have significant effect on economic perfomance in 22 countries.
\end{abstract}

Keywords: military expenditure, economic perfomance, middle east \& north africa, south asia, fixed effect model, panel data.

\section{INTRODUCTION}

The Middle East has been a chaotic area throughout history. The struggle for the use of rich land resources, conflicts and sectarian differences has been a major source of conflict in the Middle East as well as the threat posed by terrorist groups from different orientations. This situation increases the relative need and importance of the defense budget in the face of public spending and other categories, such as education and health that have a better effect on the growth and development of a country (Künü, Hopoğlu, \& Bozma, 2016).

The defense budget for protection against internal and external conflicts and national interests has an influence on the performance of a country's economic growth (Künü et al., 2016).

In the macroeconomic model, the state may make a development process as well as an evaluation of economic policy and business strategy. This is a consideration that the implications of macroeconomic policy have long-term and short-term consequences. If the government decides a policy even on a small scale it will greatly affect the economic conditions.

Guns Versus Butter Model shows the relationship between investment in defense and civil goods. In the example, people should choose when spending limited resources, whether to choose to buy weapons to invest in military or food (butter) for invest in the production of goods or perhaps both. This can be seen as an analogy to the choice between defense and civil spending in the country (Mankiw \& Ghent, 2007).

In economic formation, a country aims to meet their needs and safeguard the state's security from the threat of another country. The government always separates the portion for the military from government spending, as it has an important influence on the country's longterm economic growth. This military budget is usually associated with the fulfillment of the needs of soldiers and armaments (Issues \& Korkmaz, 2015).

\begin{tabular}{lc}
\multicolumn{2}{c}{ Table 1. Average Military Budget (\% of GDP) } \\
\hline \multicolumn{1}{c}{ Income Level } & Percentage \\
\hline LOW INCOME & $1,66 \%$ \\
LOWER-MIDDLE INCOME & $3,15 \%$ \\
UPPER-MIDDLE INCOME & $3,83 \%$ \\
HIGH INCOME & $5,78 \%$ \\
\hline
\end{tabular}

Source: The World Bank (processed)

Table 1 presents the average military budget of 22 Middle Eastern, South African (MEA) and South Asian (SAS) countries in 2000-2014. Divided into 4 groups based on income, namely: (1) Low income: Afghanistan (AFN) and Nepal (NPL). (2) Lower-middle 
Income: Egypt (EGY), India (IND), Srilanka (LKA), Marocco (MAR), Pakistan (PAK), Sudan (SDN) and Tunisia (TUN). (3) Upper-middle Income: Algeria (DZA), Iran (IRN), Jordan (JOR), Lebanon (LBN) and Turkey (TUR). (4) High Income: United Arab Emirates (ARE), Bahrain (BHR), Cyprus (CYP), Israel (ISR), Kuwait (KWT), Oman (OMN), Qatar (QAT) and Saudi Arabia (SAU).

The increase or decrease in military spending in 2000-2014 in each country is a reflection of the problems they face and the military position in dealing with the problem.

For various levels of military roles in these countries has been extended from protecting the sovereignty and territorial integrity of the country against foreign aggressors to domestic security tools and in some cases even the government. With concurrent effects on the national resources consumed by the military.

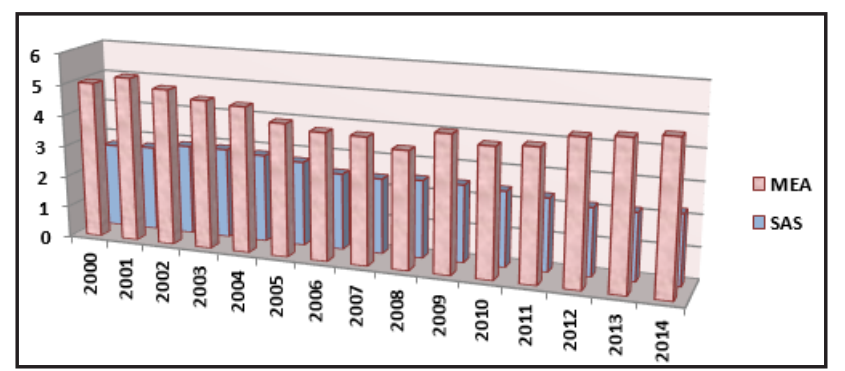

Source: The World Bank (processed)

Figure 1. Average Military Budget (\% of GDP)

Based on the Figure 1, there are fluctuations in the magnitude of the percentage of defense budget to GDP by region in Middle East, North Africa (MEA) and South Asia (SAS).

The drastic increase occurred in 2014 in the Middle East and North Africa by $4.8 \%$. Increased world military spending increased since 2011 with an average of about USD 1.7 Trillion. The increase was mainly contributed by the Middle East, Eastern Europe, Asia and other regions (sipri.org).

Issues \& Korkmaz (2015) research aims to investigate the effect of military spending in 10 Mediterranean countries on economic growth using panel data analysis from 2005-2012.

$$
y_{i t}=\alpha+X_{i t} \beta+u_{i t}
$$

The results of the study suggest that military budgets have a negative effect on economic growth because if the government plans their spending, most try to take up areas that will contribute to the development of countries into consideration.

But because of the unrest faced in countries close to the Mediterranean region, the importance of increasing state security. The government separates large shares for defense spending from their budgets. This forces them to separate fewer resources for investment in education, health and infrastructure fields that will contribute to the development of the country.

Aizenman (2006) research aims to see the relationship between military spending, the threat of the state and economic growth. This study used timeseries data from several countries in 1989-1998.

$$
g y=\underset{b_{1}<0, a_{2}>}{a_{1} m i l+a_{2}(t h r)(m i l)+b_{1} t h r+\beta X ; \ldots \ldots a_{1}<0,}
$$

The result of this study is an increase in military expenditure that has to do with how big the threat is, if the threat of a country is high, then military spending also increases. The results of the study suggest that military budgets have a negative effect on economic growth due to allocation of expenditures for investment, improvements in the quality of human resources used for countering threats and military expenditures.

Künü et al. (2016) research aimed at investigating defense spending and economic growth in the Middle East and North Africa. In this case, a panel of data for 12 countries in the period of 1998- 2012.

$$
\begin{aligned}
G D P_{i t}= & \alpha+\beta_{1} \operatorname{def}_{i t}+\beta_{2} \operatorname{pop}_{i t}+\beta_{3} f_{d i}+\beta_{i t} c o r_{i t}+\beta_{5} i n \\
& +\beta_{6} e x+\beta_{7} d u m m y+u_{i t}+\varepsilon_{i t}
\end{aligned}
$$

Based on the results, defense spending to protect internal and external conflicts affects economic growth. The results of the study suggest that military budgets have a negative effect on economic growth because the expected results obtained when looking at the impact of global financial crisis in 2009 which also has a negative impact on economic growth in 12 countries.

Knight et al. (1996) research in 22 industrialized countries and 102 developing countries in 1972-1980 using panel data,

$$
\begin{aligned}
Z_{i} t^{1}= & \theta \ln \left(n_{i}, t+g+\delta\right)+\theta_{k} \ln \left(s k_{i}, t\right)+\theta_{m} \ln \left(m_{i} t\right) \\
& +\theta \ln (s h)+\theta_{f} \ln \left(f_{i}\right)+\theta_{w} \ln \left(w_{i}\right)+y z_{i}, t^{1+\xi}, \mu_{i} \\
& +t_{i}, t
\end{aligned}
$$

The results of the study suggest that military budgets have a negative impact on economic growth, physical investment, human resource investment and foreign trade.

Mylonidis (2008) research with the data used is annual.

$$
\begin{aligned}
\text { growth }_{i t}= & \left.\alpha_{0}+\alpha_{1} g d p_{i t}+\alpha_{2} e d u_{i t}+\alpha_{3} p o p_{i t}+\alpha_{4}\right) i n v_{i t} \\
& +\alpha_{5} \operatorname{mil}_{i t}+v_{i}+\varepsilon_{i t}
\end{aligned}
$$

With the result of estimation of panel data method equation, it is found that GDP variable has negative and significant influence to economic growth, investment 
has positive and significant influence to economic growth and military expenditure has negative and significant influence to economic growth.

Yildirim \& Öcal (2016), research with the data used is annual.

$$
\begin{aligned}
& \Delta \ln y(t)= \beta_{0}+\beta_{1} \ln y(t-1)+\beta_{2} \ln s+\beta_{3} \ln (n+g+d)+ \\
& \beta_{4} \ln m(t)+\beta_{5} \ln m(t-1)+u
\end{aligned}
$$

The result of the research is a positive relationship between capital investment with population in the first year on economic growth. The results of the study suggest that military budgets have a negative effect on economic growth.

The stability of defense and security in a country will have an impact on decreasing country risk in the country so that it can attract investors to invest and impact on increasing the number or amount of investment in the country. Increased investment will then have a good impact on economic growth.

The allocation of government spending both in the defense and security sectors, education and health is the government's effort in maintaining efficiency and increasing productivity which is then expected to contribute to the improvement of economic growth.

Defense budgets include for retirement of military personnel, social services, operations and maintenance, development and military assistance (in military expenditures from donor countries) and exclude civil defense and expenditure for previous military activities, such as alimony, demobilization, conversion and destruction of weapons veterans.

The definition of military budget according to experts, among others: (1) Suryohadiprojo S. (1999)" said that the military budget has something to do with logistics that have an important role with the defense economy. This issue is linked to how much national resources are devoted to defense without adversely affecting the economy, but on the other hand has considerable opportunities to enable effective defense. (2) Hartley K. (2006)" says that defense budgeting is a significant problem for a country's defense policy. This was done to establish a difficult decision due to the rising cost of equipment and military personnel drawn from the percentage of national income.

The government's availability to fund military activities includes expenditures spent on internal law enforcement and rehabilitation of disabled veterans. Military spending is a boost for economic growth.

Classical theory argues that increased military spending will hamper economic growth. This argument is based on the premise that higher military spending will result in private investment, domestic savings and lower consumption due to lower aggregate demand.
The higher military spending will increase interest rates that will push out private investment.

Meanwhile, Keynesian argues that increased military burdens stimulate demand, increase in power, purchase national output and create positive externalities (Narayan \& Singh, 2007).

The Government has in some ways made a policy to regulate its expenditures, one of its policies being for military budgets. Tthere is a positive relationship between military spending and economic growth. Economic growth is the development of activities in the economy that causes goods and services produced in the community increases.

Thus, military spending is included in the calculation of state expenditures. In other words, as part of government consumption and government investment. Military spending provides a favorable macroeconomic economic stimulus as well as military spending which will drive modernization, technological advances become a source of technological development in a country's industry.

Endogenous Growth Theory explains that government budgets have an important influence on long-term economic growth. One of the requirements to boost growth is to increase indirect investment in the formation of human resources and foreign private investment.

Theoretically, an increase in defense budget through increased taxes will lead to a decrease in the ability to save and private companies will lack capital for investment. Demand for higher defense spending may have serious macro consequences if increased military expenditures are financed by increasing the supply of money, borrowing from abroad or domestically, or by depleting foreign exchange stocks.

As for the indirect effect of the defense budget on external debt through the purchase of expensive advanced technology or half the goods required by the domestic defense industry from abroad. If the government allocates its budget to the military it will affect investment. Since the possibility of allocation for infrastructure, education, health, etc. will be depleted for military budgeting.

\section{METHOD}

The object of this study is the relationship between military budget and economic growth in some countries MENA (Middle East and North Africa) and SAS (South Asia), namely Afghanistan, United Arab Emirates, Bahrain, Cyprus, Algeria, Egypt, India, Iran, Israel, Jordan, Kuwait, Lebanon, Sri Lanka, Morocco, Nepal, Oman, Pakistan, Qatar, Saudi Arabia, Sudan, Turkey and Tunisia. 
With the dependent variable of economic growth measured by GDP per capita as well as independent variables, among others, military budget, gross fixed capital formation, human capital and final consumption budget.

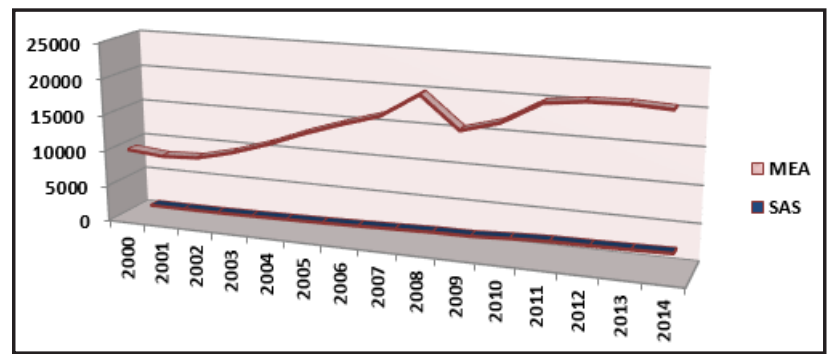

Source: The World Bank (processed)

Figure 2. GDP Per Capita (USD)

The variable used to measure economic performance. The data used are the years 2000-2014 from the average of 22 countries in Middle East \& North Africa (MEA) and South Asia (SAS). Based on the graph above, there are fluctuations and differences that are very prominent between MEA and SAS economic growth.

The average for the Middle East \& North Africa (MEA) is US \$ 16185.67 with the highest year in 2014 of US \$21428,43. Meanwhile, the average South Asia (SAS) of US \$ 1080.61 with the highest year in 2014 amounted to US \$ 1861.66.

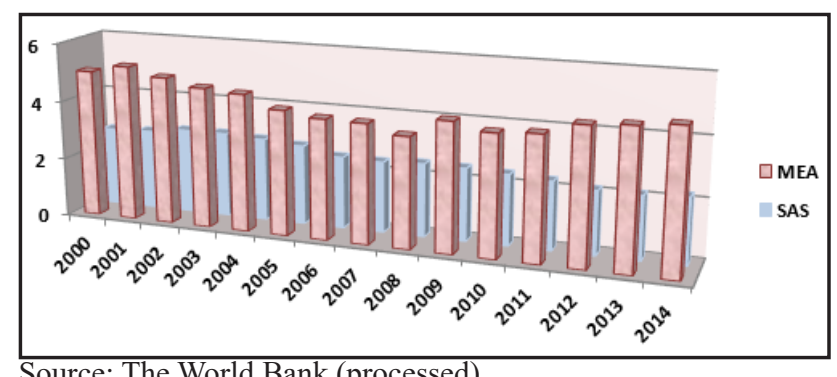

Source: The World Bank (processed)

Figure 3. Military Budget (\% of GDP)

Based on Figure 3, do the military budget affects to economic performance? There are data for the years of 2000-2014 from the average of 22 countries in Middle East \& North Africa (MEA) and South Asia (SAS) showed fluctuations in both areas. For an average MEA of $4.5 \%$ with the highest year 2001 of $5.28 \%$. Meanwhile, the average SAS is $2.52 \%$ with the highest year 2003 of $2.89 \%$.

This military budget is seen of GDP, it cannot be denied the Middle East has a higher military budget higher than South Asia. As the growth of the Middle East is much higher than that of South Asia and the military needs in the Middle East are greater due to conflict and chaos than in South Asia.

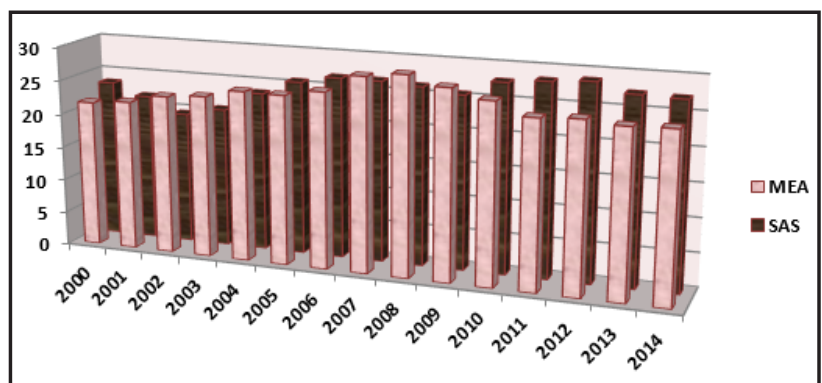

Source: The World Bank (processed)

Figure 4. Gross Capital Formation (\% of GDP)

Based on the Figure 4, gross fixed capital formation for 2000-2014 from the average of 22 countries in the Middle East (MEA) and South Asia (SAS) shows fluctuations in both areas. For an average MEA of $25.15 \%$ with a 2008 year high of $29.17 \%$. Meanwhile, the average SAS of $25.27 \%$ with the year 2012 highest of $28.47 \%$.

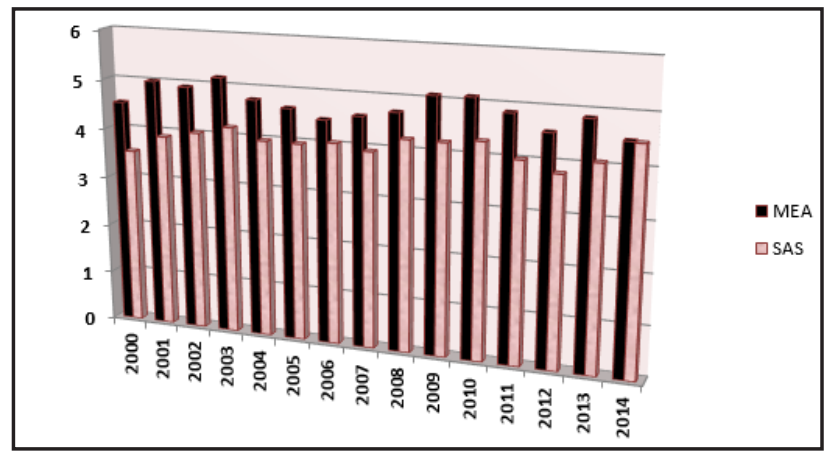

Source: The World Bank (processed)

Figure 5. Human Capital (\% of GDP)

Based on the graph above, human capital for health and education expenditures for the years 2000-2014 reached from the average of 22 countries in the Middle East \& North Africa (MEA) and South Asia (SAS) seen fluctuations in both areas. Areas in South Asia are lower than the Middle East. For an average MEA of $4.78 \%$ with a 2003 year high of $5.15 \%$. Meanwhile, the average SAS of $4.04 \%$ with the highest year 2014 of $4.48 \%$.

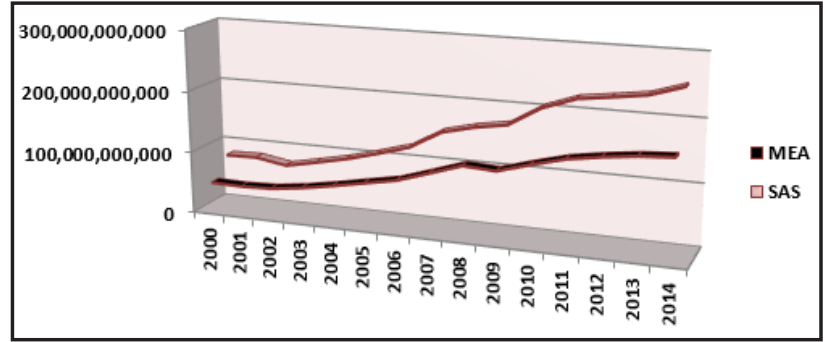

Source: The World Bank (processed)

Figure 6. Final Consumption Expenditure (USD) 
Based on the graph above, there is a fluctuation with the dominant increase in final consumption for 2000-2014 from the average of 22 countries in Middle East \& North Africa (MEA) and South Asia (SAS). For an average MEA of \pm 99 billion with a 2014 year high of \pm 160 billion. Meanwhile, the average SAS of \pm 151 billion with the highest year 2014 of \pm 252 billion.

As South Asian countries are dominated by developing countries compared to the Middle East, consumption in South Asia tends to be higher than in the Middle East.

The model used in this study refers to previous research ever conducted based on the theory of military expenditure and economic growth. To test the influence of each variable used. Model:

$$
L N G D P_{i t}=\beta_{0}+\beta_{1} \operatorname{MIL}_{i t}+\beta_{2} G C F+\beta_{3} H U M C A P_{i t}+
$$

\begin{tabular}{|c|c|}
\hline LNGDP $_{\text {it }}$ & : logaritma economic growth rate (GDP \\
\hline MIL $_{\text {it }}$ & : military budget \\
\hline $\mathrm{GCF}_{\text {it }}^{\text {it }}$ & : gross capital formation \\
\hline HUMCAP $_{\text {it }}$ & : human capital \\
\hline LNCONS $_{\text {it }}$ & $\begin{array}{l}\text { logaritma final consumption } \\
\text { expenditure (this variable used log } \\
\text { to minimize numbers) }\end{array}$ \\
\hline$\varepsilon_{\text {it }}$ & : error term \\
\hline & : observed countries, 2004-2014 \\
\hline & : constants \\
\hline$-P_{4}$ & : coefficients \\
\hline
\end{tabular}

Which:

\section{RESULTS AND DISCUSSION}

Models adapted (Knight et al., 1996) model with some changes and additions to independent variables using variables is associated to their dependent variables. Based on the tests (Chow Test and Hausman Test) that have been done, the hypothesis shows that fixed effect test is better used than random effect test.

To determine the method to be used in research between approach of common effect or fixed effect approach, Chow Test can be used (Gujarati \& Porter, 2004) based on the results of data processing obtained results as Table 2 .

Table 2. Chow Test

\begin{tabular}{cccc}
\hline Test Summary & Statistic & d.f. & Prob. \\
\hline Cross-section F & 2755,970723 & $(21,285)$ & 0,0000 \\
\hline$\alpha=5 \%$ & \multicolumn{4}{c}{ F-table $=1,593098$} \\
\hline
\end{tabular}

Source: processed data

Based on Table 2, F-Statistic $>$ F-Tabel, then $\mathrm{H}_{0}$ which states that the selection of the best common effects model is rejected.
The next test is to perform Hausman test to determine the random effect or fixed effect approach. From the results of data processing using Hausman test, obtained in Table 3.

Table 3. Hausman Test

\begin{tabular}{cccc}
\hline Test Summary & Chi-Sq. Statistic & Chi-Sq. d.f. & Prob. \\
\hline Cross-section Random & 11,900233 & 4 & 0,0181 \\
\hline$\alpha=5 \%$ & & $\begin{array}{c}\text { Chi-Square table } \\
=9,487729\end{array}$ \\
\hline
\end{tabular}

Source: processed data

Based on Table 3, Chi Square $\left(\mathrm{X}^{2}\right)$ statistic $>$ Chi Square $\left(\mathrm{X}^{2}\right)$ table, then $\mathrm{H}_{0}$ is rejected, which is estimation in panel model would be better if it uses fixed effect model.

\begin{tabular}{|c|c|c|c|c|}
\hline Variable & Coefficient & $\begin{array}{l}\text { Std. } \\
\text { Error }\end{array}$ & t-Statistic & Prob. \\
\hline $\mathrm{C}$ & -5.608884 & 0.206063 & -27.21929 & 0.0000 \\
\hline MIL? & -0.012197 & 0.002125 & -5.739672 & 0.0000 \\
\hline GCF? & 0.000952 & 0.000346 & 2.750496 & 0.0064 \\
\hline HUMCAP? & 0.000205 & 0.000398 & 0.515211 & 0.6068 \\
\hline CONS? & 0.864295 & 0.018328 & 47.15823 & 0.0000 \\
\hline AR(1) & 0.886403 & 0.026718 & 33.17642 & 0.0000 \\
\hline \multicolumn{5}{|l|}{$\begin{array}{l}\text { Fixed } \\
\text { Effects } \\
\text { (Cross) }\end{array}$} \\
\hline _AFG-C & -0.433281 & \multicolumn{2}{|c|}{ _ $\mathbf{L B N}-\mathbf{C}$} & 0.381659 \\
\hline _ARE-C & 0.397707 & \multicolumn{2}{|c|}{ _LKA-C } & -0.141652 \\
\hline _BHR-C & 1.126692 & \multicolumn{2}{|c|}{ _MAR_C } & -0.309982 \\
\hline _CYP_C & 1.146075 & \multicolumn{2}{|c|}{ _NPL_-C } & -0.418982 \\
\hline _DZA-C & -0.173466 & \multicolumn{2}{|c|}{ _OMN_C } & 0.868065 \\
\hline _EGY_C & -0.755772 & \multicolumn{2}{|c|}{ _PAK-C } & -1.061180 \\
\hline _IND_-C & -1.681672 & \multicolumn{2}{|c|}{ _QAT $-\mathbf{C}$} & 1.178416 \\
\hline _IRN-C & -0.478619 & \multicolumn{2}{|c|}{ _SAU-C } & 0.052362 \\
\hline _ISR-C & 0.379515 & \multicolumn{2}{|c|}{ _SDN_C } & -0.538438 \\
\hline _JOR-C & 0.199160 & \multicolumn{2}{|c|}{ _TUN-C } & 0.066364 \\
\hline _KWT_-C & 0.895116 & \multicolumn{2}{|c|}{ _TUR-C } & -0.596119 \\
\hline R-squared & & \multicolumn{2}{|c|}{0.999704} & \\
\hline F-statistic & & \multicolumn{2}{|c|}{34000.69} & \\
\hline Observation & & \multicolumn{2}{|c|}{289} & \\
\hline $\begin{array}{l}\text { Durbin- } \\
\text { Watson stat }\end{array}$ & & \multicolumn{2}{|c|}{1.849249} & \\
\hline
\end{tabular}

Table 4. Result of Fixed Effect Model

Based on Table 4 of data processing by using panel data regression about the effect of military budget variable on economic perfomance and other variables in 23 countries in 2000-2014 are shown pretty good 
results. This study uses panel data analysis with fixed effect model. The results of model estimation suggest that military budget has a significant negative effect on economic perfomance, while gross capital formation, final consumption expenditure have significant positive effect on economic perfomance. Meanwhile, human capital does not have significant effect on economic perfomance in 22 countries.

\section{CONCLUSION}

Based on the results of data processing by using panel data regression about the effect of military budget variable on economic perfomance and other variables in 23 countries in 2000-2014, it can be obtained these following conclusion: (1) Military budget has a significant negative effect on economic perfomance. (2) Gross Fixed Capital Formation has a significant positive effect on economic perfomance. (3) Human Capital does not significantly affect the economic perfomance. (4) Final Consumption Budget has a significant positive effect on economic perfomance.

\section{REFERENCES}

Aizenman, J., \& Glick, R. 2006. Military Expenditure, Threats, and Growth. The Journal of International Trade \& Economic Development, 15(2), 129-155. http://doi.org/10.1080/09638190600689095

Gujarati D. N., \& Porter, D. C. 2004. Basic Econometrics. New York (4th ed.). The McGraw-Hill. http://doi. org/10.1126/science.1186874

Hartley, K. 2006. 'Defence R\&D: Data issues', Defence and Peace Economics, 17, 3, June, pp169- 175.

Issues, F., \& Korkmaz, S. 2015. The Effect of Military Spending on Economic Growth and Unemployment, 5(1), 273-280.
Knight, M., Loayza, N., \& Villanueva, D. 1996. The peace dividend: Military spending cuts and economic growth. International Monetary Fund. Staff Papers - International Monetary Fund, 43(1), 1. http://doi.org/10.2307/3867351

Künü, S., Hopoğlu, S., \& Bozma, G. 2016. Conflict , Defense Spending and Economic Growth in the Middle East : A Panel Data Analysis, 6(1), 80-86.

Mankiw, N. G., \& Ghent, L. 2007. Instructor â€TM s Manual with Solutions Manual Principles of Macroeconomics. Retrieved from http://www. thomsonrights.com

Mylonidis, N., 2008. Revisiting the nexus between military spending and growth in the European Union. Defence and Peace Economics, 19(4), pp.265-272.

Narayan, P. K., \& Singh, B. 2007. Modelling the Relationship Between Defense Spending and Economic Growth for the Fiji Islands. Defence and Peace Economics, 18(4), 391-401. http://doi. org/10.1080/10242690600807924

Suryohadiprojo S. 1999. Hubungan-Sipil Militer di Indonesia: Suatu Pembahasan, sebuah makalah yang disajikan dalam Seminar Nasional Mencari Format Baru Hubungan Sipil-Militer, Jakarta: FISIP UI

The World Bank. 2008. Global Economic Prospects. Retrieved June 23, 2017, from http://www. worldbank.org/en/publication/global-economicprospects.

The World Factbook - Central Intelligence Agency. (n.d.). Retrieved July 2, 2017, from https://www. cia.gov/library/publications/the-world-factbook/

Yildirim, J., \& Öcal, N. 2016. Military expenditures, economic growth and spatial spillovers. Defence and Peace Economics, 27(1), 87-104. http://doi. org/10.1080/10242694.2014.96024 